Egypt. J. Aquat. Biol. \& Fish., Vol. 11, No.2: 119-143(2007) ISSN 1110-6131

\title{
THE BIOLOGICAL LOAD OF SILVER CARP CAGES IN THE RIVER NILE AND THEIR EFFECTS ON WATER QUALITY AND GROWTH PERFORMANCE
}

\author{
Ibrahim M. Shaker ${ }^{1}$ and Ahmed A. Mahmoud ${ }^{2}$ \\ 1- Limnology Department and 2- Aquaculture Department Central \\ Laboratory for Aquaculture Research,(CLAR) Abbassa, Sharkia, Egypt. \\ Corresponding author:dr_ibrahim_sh@yahoo.com
}

Key words: Cages, intensive, River Nile, growth performance, water quality, biological load, Silver carp.

\begin{abstract}
Qilver carp fingerlings were stocked in cages at three different $\checkmark$ densities. Four replicates cages $6 \times 9 \times 4 \mathrm{~m}$ were cultured for 150 days during two seasons from February to December 2004. These stocking densities of silver carp (initial weight $5-10 \mathrm{~g}$ ) were tested in three locations; El-Mahmoudia (8, 10 and $\left.12 \mathrm{fish} / \mathrm{m}^{3}\right)$; Fazara $(6,8$ and 10 fish $/ \mathrm{m}^{3}$ ) and Edfina $\left(4,6\right.$ and $\left.8 \mathrm{fish} / \mathrm{m}^{3}\right)$ in cages suspended in the River Nile at each location in two seasons. The impacts of cages on water quality were investigated. Results obtained are summarized as follows:

1- Water temperature ranged from 26.5 to $27.4^{\circ} \mathrm{C}$ in all cages at all locations.

2- Values of $\mathrm{pH}, \mathrm{DO}, \mathrm{NH}_{4}, \mathrm{NH}_{3}, \mathrm{NO}_{2}, \mathrm{TP}, \mathrm{OP}$ and chlorophyll a increased significantly down stream after passing the cages.

3- SD decreased sharply after the site of cages at all locations.

4- Survival rate was affected by location

5- Location released affects on cage production.

The maximum production rate achieved was $19.87 \mathrm{~kg} / \mathrm{m}^{3}$ in first season with initial weight of $10 \mathrm{~g} \mathrm{fish} / \mathrm{m}^{3}$ at El-Mahmoudia. The results of this study suggest that cages in the River Nile and stocking density are more than load on water.

We can suggest that necessary codification the use of water in the River Nile in cages culture, also, transferring these cages in lakes.
\end{abstract}

\section{INTRODUCTION}

Cage fish culture is a viable alternative to traditional techniques of rearing, due to its practicability and, mainly, low costs Beveridge (1996). 
In recent decades, net-cage aquaculture has become one of the main patterns of the intensive fish-culture in the lakes, reservoirs and even rivers in China.

Freshwater aquaculture is of great importance in commercial fisheries in China, thus it supplies more than one third of the total freshwater fishery production of the world (Longgen Guo and Zhongjie $\mathrm{Li}, 2003)$.

Cage aquaculture is one of the main freshwater intensive culture patterns in Egypt, due to its benefits in terms of increased fish production and its feasible profit. During the fish cage culture, a large amount of waste materials was brought into the water directly (Longgen Guo and Zhongjie Li , 2003).

Site selection is a key factor in any aquaculture operation, affecting both success and sustainability of the culture activity. The correct choice of the site in any aquatic farming operation is vitally important since it can greatly influence economic viability by determining capital outlay, and, by affecting running costs, rates of productions and mortality factors. It is impractical to try control water quality parameters in cage culture systems, therefore culture of any species must be established in geographical regions having adequate water quality and exchange (Pérez et al., 2003).

Cage culture, as with any aquaculture venture, requires good water quality, thus water properties strongly affect the choice of an aquaculture site. Hence, cages should be located in uncontaminated areas by industrial, municipal and agricultural pollutants. Other water quality parameters, such as temperature, $\mathrm{pH}$, presence of nitrogenous compounds, dissolved oxygen, etc., should be within the ranges that provide life support and growth for the cultured species. The correct choice of sites is vitally important since it influences the economic viability of the facility (Lawson,1995). However, the availability of suitable areas for aquaculture is diminishing because of water quality degradation. Therefore, the first prerequisite for sustainable aquaculture is an adequate aquaculture resource allocation system.

Stocking density is one of the most important variables in aquaculture because it directly influences survival, growth, behavior, health, water quality, feeding and production. In cage culture, optimum stocking densities and carrying capacities vary with species, size of fish, size of cages, rate of water exchange, and size of ponds and length of growing season (Kilambi et al., 1977; Chua and Teng, 1979; Coche, 
1982; McGinty, 1991; Duarte et al., 1994; Beveridge, 2002; Chua and Tech, 2002; Masser, 2004). Production strategies often involve 'the manipulation of densities by harvesting, grading and transferring fish to larger-mesh cages during the culture period (Campbell, 1985; Schwedler et al., 1989; Beveridge, 1996, 2002; Lazur, 1996; Ahmad et al., 1999; Liao et al., 2004). Consequently, optimum stocking densities need to be determined for each species and production phase to enable efficient management and to maximize production and profitability. Therefore, the objectives of the present study are to evaluate of these cages in the River Nile and to determine the impacts of these cages and stocking density on water quality and biological load.

\section{MATERIALS AND METHODS}

The present study was carried out in the River Nile branch Rasheed, Egypt, at three locations; El-Mahmoudia, Fazara and Edfina. The experimental work was conducted in floating cages. Experimental cages were fixed on the water stream at the main water inlet to the Mediterranean Sea, where Rasheed branch minded. At each location three stocking densities were tested $\left(8,10\right.$ and $\left.12 \mathrm{fish} / \mathrm{m}^{3}\right)$ for El-Mahmoudia; $\left(6,8\right.$ and $\left.10 \mathrm{fish} / \mathrm{m}^{3}\right)$ for Fazara and $\left(4,6\right.$ and $\left.8 \mathrm{fish} / \mathrm{m}^{3}\right)$ for Idfina. Moreover, two initial weights; 5 and $10 \mathrm{~g} / \mathrm{fish}$ were investigated. Each stocking density was performed in four replicates. The study was performed in two successive rearing seasons where fish initial weights were 5 and $10 \mathrm{~g} /$ fish for two seasons. The experimental cages were of diameters $6 \times 9 \times 4 \mathrm{~m} /$ cage with a total water volume of $216 \mathrm{~m}^{3} /$ cage. The first season expanded from $15^{\text {th }}$ February 2004 to $15^{\text {th }}$ July of the same year and the second season started in $15^{\text {th }}$ July and lasted in $25^{\text {th }}$ December of the same year. In both seasons the experiments lasted in 150 days. During the first month fish were reared in cages with nets of a very low diameter ( $80 \mathrm{mesh})$, then fish were transferred to cages with nets of (10 mesh) until the harvest. Cages were covered with nets of the same diameter during all experimental period. During both seasons a total of 24 cages were used at each location; three locations, within each three stocking densities in four replicates each.

\section{Sampling:}

Water samples from the cages were collected monthly, for physico-chemical analysis (temperature ${ }^{\circ} \mathrm{C}$, dissolved oxygen $\mathrm{DO}$ as $\mathrm{mg} / \mathrm{l}$ and saturation of oxygen as percentage, using YSI $6600 \mathrm{CID}$ (yellow spring Instruments, Ohio, USA).In each cage $\mathrm{SD}, \mathrm{NH}_{4}$ (total ammonia), 
$\mathrm{NO}_{2}$ (Nitrite) and $\mathrm{NO}_{3}$ Nitrate were measured by Hack apparatus according to APHA (2000), $\mathrm{NH}_{3}$ was calculated by conversion Tables for pH and temperature (Boyd, 1990). Total phosphorus (TP), Orthophosphate (OP) and chlorophyll " $a$ " were measured according to APHA (2000). Qualitative and quantitative estimates of phytoplankton and zooplankton were also recorded monthly according to APHA (2000). At the end of the experiment, fish were haryested, counted and weighed. The growth parameters were calculated as follows:

Daily gain (DG) $=\left(W t_{2}-W t_{1}\right) / T$;

Specific growth rate $(\mathbf{S G R})=\left(\mathrm{Ln} W t_{2}-W t_{1}\right) \times 100 / \mathrm{T}$; where $\mathrm{Wt}_{1}$ is the initial weight in grams, $W_{2}$ is the second weight in grams, and $T$ is the period in days

Condition factor $(K)=$ Body weight $/$ Total length $^{3} \times 100$.

Statistical analysis was performed using the analysis of variance (ANOVA). Duncan's Multiple Range Test Duncan (1955) was used to determine the significant differences between means at $\mathrm{P}<0.05$. Standard errors of treatment means were also estimated. All statistical evaluations were carried out using Statistical Analysis Systems (SAS) program (SAS, 2000).

\section{RESULTS AND DISCUSSION}

Data of tables (1-4), show the water quality parameters. The average values of water temperature ranged between 27 to $27.4^{\circ} \mathrm{C}$ during experimental period at all locations during both tested seasons. These results clear that the water temperature did not differ significantly the among all cages in all locations. The $\mathrm{pH}$ values ranged between 7.6-7.98; 8.1-8.5 and 8.5-9.13 in El-Mahmoudia; Fazara and Idfina respectively. These results show that the $\mathrm{pH}$ values increased with down stream, i.e, the $\mathrm{pH}$ values was significantly higher in Idfina than other locations, also, $\mathrm{pH}$ values in Idfina > Fazara > El-Mahmoudia, which may be due to the increase of phytoplankton and increase photosynthetic uptake $\mathrm{CO}_{2}$ and of substituted hydroxyl ions. These results are in good agreement with those obtained by Masser (2004); Shaker (2006) and Rowland et al.(2006). The same trend was observed in DO and saturation percentage of DO. Secchi disc visibility (SD) is the first important parameter as an indicator of phytoplankton production in water. The increase in SD reading indicated the clear of water, while the reading decrease indicated the blcom of water. From the results in tables (1-4), it is clear that the SD decreased water down stream. These results are in good agreement with those obtained by shaker et al.(2002), Nagler et al. (2003) and Shaker Abdel- 
Aal (2006) who found that the increase of organic and mineral fertilization increased phytoplankton and decreased SD. Secchi disc visibilities were significantly low the down stream water due to the accumulation of organic compounds, macronutrients and then transfer by water to these locations. These results clear that the highly intensive of cages and highly intensive of fish in cages in all locations led to increase of biological lood in water. The same trend was observed in $\mathrm{NH}_{4}, \mathrm{NH}_{3}$, $\mathrm{NH}_{2}$ and $\mathrm{NO}_{3}$ (nitrogen compound). These results indicated that the silver carp cages deteriorate water quality in River Nile by increasing organic and inorganic compounds. These results may be due to the intensive of cages at low area and intensive of silver carp in cages. These results are in agreement with these data obtained by chlorophyll ' $a$ ' analyses in water, indicating high correlation between organic compound, and chlorophyll ' $a$ ' in water. The chlorophyll ' $a$ ' increased down stream; so the trend was Idfina >Fazara > El-Mahmoudia. These results are in agreement with those obtained by Shaker (2006), who reported that the increase of organic, inorganic compound and macronutrient increased chlorophyll ' $a$ ', phytoplankton and zooplankton. The average concentration of total phosphorus (TP) and orthophosphate (OP) were significantly decreased in El-Mahmoudia than Fazara and Idfina. These results may be due to the leaching of these compound and transfer with down stream. ChlorophyIl 'a', phytoplankton and zooplankton were significantly increased at Idfina than other locations. These results are in agreement with that obtained by Shaker and Abdel-Aal (2006). As presented in tables (5-9) and Fig (1), the average density of phytoplankton, and zooplankton increased with down stream water. These results indicated that the average numbers of phytoplankton and zooplankton were higher significantly $(p<0.05)$ in Idfina than that of Fazara and El-Mahmoudia. These results clear that the mass production of phytoplankton and zooplankton depend on organic lood in water.

The average annual number of total phytoplankton were 1518.92, 2701.67 and $6648.25 \mathrm{org} / \mathrm{l}$ for El-Mahmoudia, Fazara and Idfina respectively. Zooplankton were $361.17,934.58$ and $1397.92 \mathrm{org} / \mathrm{l}$ for the same location respectively, (Table 9) and Fig (1). These results clear that there is a highly significant difference among the three locations for phytoplankton and zooplankton. Fish production; growth performance and fish carcass are illustrated in Tables (10-14).The final weight of individual fish were $1295,1415,1517,1175,1173$ and $1033 \mathrm{~g}$ at ElMahmoudia, with initial weight $5 \mathrm{~g}$ per fish at stocking $8,10,12$ in season 
1 and 2 , while, at $10 \mathrm{~g}$ per fish were $1842,1887,1816,1559,1420$ and 1391 for the same stocking and seasons 1 and 2 . These results show the significantly effect of initial weight on final weight, net gain and daily gain of fish in all cages. Generally, the final weight, net gain, daily gain increased significantly with the increasing initial weight of fish in each location. These results are in agreement with these obtained by Shaker $e t$ al. (2002), Shaker and Abdel Aal ,(2006) and Macleod et al. (2006) who found a positive correlation between initial weight and growth performance of fish.

Generally, the highest final weight, net gain and daily gain were recorded in El-Mahmoudia then Fazara and Idfina. The survival rate did not differ significantly by stocking density or season in the same location. While, the survival rate decreased significantly with down stream water. The highest survival rate was recorded in El-Mahmoudia than Fazara and Idfina.

The positive correlation was found between final weight and muscle; head skeleton and stomach in fish at each location. The stocking density did not effect on carcass test. A muscles percentage ranged from 46 to $52 \%$, the highest percentage recorded in El-Mahmoudia location.

The average final weight of fish at the three locations, El-Mahmoudia, Idfina and Fazara at stocking density 8 fish $/ \mathrm{m}$ were 1295,910 and $600,1175,854$ and $450 \mathrm{~g}$ respectively, when initial weight $5 \mathrm{~g} /$ fish. While at $10 \mathrm{~g}$ was 1842,1370 , and 760 and 1559,1179 and $550 \mathrm{~g}$. These results clear that the final weight did not significantly differ by stocking density, while affected by location i.e the effect of water quality on final weight of fish in cages at each location with different stocking density and different initial weight.

From the data presented in Table (13) about growth performance and carcass compositions of silver carp in cages under different initial weight, season and location regardless stocking density it is clear that the growth performance of fish increased with increasing initial weight in all locations.

From the above results we can conclude that the cage culture in Egypt need to rationing along the River Nile, also, the stocking density in cages should be low to keep good water quality of the River Nile . 


\section{REFRENCES}

Ahmad, T. A.; El-Zahar, C. and Wuan, T.O. (1999). Nursing and production of the grouper Epinephelus coioides at different stocking densities in tanks and sea cages. Asian Fish. Sci. 12:267276.

American Public Health Association (APHA), (2000). Standard Methods for the Examination of Water and Wastewater ( $16^{\text {th }}$ edition). Washington, D. C.

Association of Official Analysis Chemists (AOAC) (1990). Official Methods of Analysis, Association of Official Analysis Chemists. Washington. D. C.

Beveridge, MCM., (1996). Cage Aquaculture. Fishing News Books, Carlton. 346 pp.

Beveridge, M.C.M., (2002). Overview of cage culture. In: Woo,P.T.K., Bruno, D.W., Lim, L.H.S. (Eds.), Diseases and Disorders of Finfish in Cage Culture. CABI Publishing, Oxon, pp. 41-59.

Boyd, C.E. (1990). Water Quality in Ponds for Aquaculture. Aubum University, Alabama. $482 \mathrm{pp}$.

Campbell, D. (1985). Large scale cage farming of Sarotherodon niloticus. Aquacult. 48:57-69.

Chua, T. E. and Tech, E. (2002). Introduction and History of Cage Culture. In: Woo, P.T.K., Bruno, D.W., Lim, L.H.S. (Eds.y. Diseases and 306 S.J. Rowland et al. / Aquacult. 253 (2006) 30I308 Disorders of Finfish in Cage Culture. CABI Publishing, Oxor. pp. $1-39$.

Chua, T. E. and Teng, S. K. (1979).Relative growth and production of the estuary grouper Epinephelus salmoides under different stocking densities in floating net-cages. Mar. Biol. 54: 363-372 
Coche, A. G. (1982). Cage culture of tilapias. In: Pullin, R.S.V., LoweMcConnell, R.H. (Eds.), The Biology and Culture of Tilapias. ICLARM, Manila, Philippines, pp. 205- 246.

Duarte, S. A.; Nelson, R. G. and Masser, M.P. (1994). Profit-maximising stocking rates for channel catfish in cages. J. World Aquac. Soc. 25 (3): 442- 447.

Kilambi, R.V., Adams, J.C., Brown, A.V. and Wickizer, W.A. (1977). Effects of stocking density and cage size on growth, feed conversion and production of rainbow trout and channel catfish. Prog. Fish-Cult. 39: 62-66.

Lawson, T. B. (1995). Fundamentals of Aquaculture Engineering. Chapman \& Hall, New York. 355 pp.

Lazur, A. M. (1996). The effects of periodic grading on production of channel catfish cultured in cages. J. Appl. Aquac. 6: 17-24.

Liao, I. C.; Huang, T.-S.; Tsai, W. S.; Hseuh, C. M.; Chang, S. L. and Lean, E. M. (2004). Cobia culture in Taiwan: current status and problems. Aquacult. 237:155 - 165 .

Longgen G. and Zhongjie, Li, (2003). Effects of nitrogen and phosphorus from fish cage-culture on the communities of a shallow lake in middle Yangtze River basin of China Aquacult. 226: 201-212

Macleod, C. K.; Moltschaniwskyj, A. N. and Crawford, C. M. (2006). Evaluation of short-term fallowing as a strategy for the management of recurring organic enrichment under salmon cages. Marine Pollution Bulletin.

Masser, M.P. (2004). Cages and in-pond raceways. In: Tucker, C.S., Hargreaves, J.A. (Eds.), Biology and Culture of Channel Catfish. Elsevier, Sydney, pp. $530-544$.

McGinty, A.S. (1991). Tilapia production in cages: effects of cage size and number of non-caged fish. Prog. Fish-Cult. 53:246 - 249.

Nagler, P. L.; Edward, P.G; Nelson. S.G. and Napolean S. (2003). Effects of Fertilization treatment and stocking density on the growth and 
production of the economic seaweed Gracilaria parvispora (Rhodophyta) in cage culture at Molokai, Hawaii. Aquacult. 219: 379-391.

Pe'rez, O. M.; Ross, L. G.; Telfer, T. C. and Barquin, L.M. C. (2003). Water quality requirements for marine fish cage site selection in Tenerife (Canary Islands): predictive modelling and analysis using GIS. Aquacult. 224: 51-68

Rowland, J. S.; Mifsuda, C. ; Nixona,M. and Boyd, P.(2006). Effects of stocking density on the performance of the Australian freshwater silver perch (Bidyanus bidyanus) in cages. Aquacult. 253: 301308

Schwedler, T.E.; Tomasso, J.R. and Collier, J.A., (1989). Production characteristics and size variability of channel catfish reared in cages and open ponds. J. World Aquac. Soc. 20 (3):158-161.

Shaker, I. M. A.; Ibrahim, N. A. ; Dawa, M. A. A. and Zakar, A. H.(2002). Effect of stocking density on water quality and mullet growth in earthen ponds at Sahl El-Teena-Senai- Egypt. The $6^{\text {th }}$ Vet. Med. Zagazig. Conference, 7-9 Sep. 2002, Hurghada, Egypt.

Shaker, I. M. (2006). Water hyacinth as a biological treatment for sewage wastewater in aquaculture earthen ponds. Egypt. J. Aquat. Biol. \& Fish. 10: (1):1-20.

Shaker, I. M. and Abdel-Aal, M.M. (2006). Growth performance of fish reared under different densities in semi-intensive and extensive earthen ponds. Egypt. J. Aquat. Biol. \& Fish. 10, (4):109-127.

Statistical Analysis System (SAS) (2000). SAS program Ver 6.12, SAS institute incorporation, Cary, NC 27513 USA. 


\begin{tabular}{|c|c|c|c|c|c|c|c|c|c|c|c|c|}
\hline 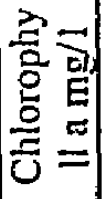 & $\frac{ \pm}{m}$ & $\frac{\infty}{n}$ & $\begin{array}{l}\mathscr{g} \\
\frac{j}{m}\end{array}$ & o. & $\hat{n}$ & $\begin{array}{l}a \\
\dot{m}\end{array}$ & $\begin{array}{l}0 \\
0 \\
\dot{m}\end{array}$ & $\frac{N}{n}$ & $m$ & $\vec{m}$ & $\begin{array}{l}0 \\
\dot{m} \\
\text { m }\end{array}$ & $\stackrel{\dot{m}}{m}$ \\
\hline $\begin{array}{lll}0 & & \\
0 & 0 & 3\end{array}$ & $\begin{array}{l}0 \\
\dddot{0}\end{array}$ & $\stackrel{0}{0}$ & 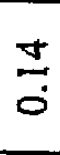 & 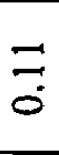 & $=$ & 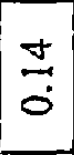 & $\stackrel{\infty}{=}$ & $\frac{\infty}{0}$ & $\frac{n}{0}$ & $\frac{0}{0}$ & $\frac{0}{0}$ & $\frac{n}{0}$ \\
\hline 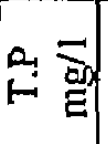 & $\begin{array}{l}0 \\
m \\
0\end{array}$ & $\begin{array}{l}0 \\
⿱ \\
0\end{array}$ & $\stackrel{\circ}{m}$ & $\ddot{\sigma}$ & $m$ & m & 范 & $\stackrel{\infty}{m}$ & $\stackrel{m}{m}$ & $\ddot{\circ}$ & $\begin{array}{l}\infty \\
n \\
0\end{array}$ & \\
\hline $\begin{array}{ll}\rho^{n} & = \\
z & 0\end{array}$ & $\overrightarrow{0}$ & $\ddot{0}$ & $\ddot{0}$ & 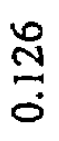 & $\begin{array}{l}y \\
0\end{array}$ & $\stackrel{n}{0}$ & $\stackrel{\simeq}{a}$ & $\frac{ \pm}{0}$ & $\overrightarrow{0}$ & $\frac{0}{0}$ & $\frac{ \pm}{0}$ & E \\
\hline 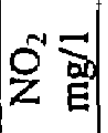 & 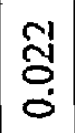 & ช̊ & $\stackrel{ }{\delta}$ & 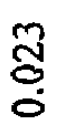 & 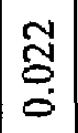 & 范 & 吉 & త్ర & రั & ষ্் & $\begin{array}{l}0 \\
0 \\
0\end{array}$ & $\begin{array}{l}S \\
O \\
0\end{array}$ \\
\hline $\begin{array}{ll}m & - \\
Z & E\end{array}$ & $\frac{m}{m}$ & $\stackrel{8}{\circ}$ & $\frac{\square}{0}$ & $\ddot{0}$ & $=$ & $\frac{0}{0}$ & $\frac{0}{0}$ & $\ddot{0}$ & $\stackrel{0}{0}$ & $\frac{0}{0}$ & $\Xi$ & $\ddot{0}$ \\
\hline 氞 & 0 & 웅 & $\exists$ & $\stackrel{m}{m}$ & $\stackrel{\infty}{=}$ & 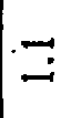 & ণิ & 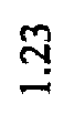 & $\underset{\sim}{\simeq}$ & $\bar{n}$ & $\cong$ & $\stackrel{0}{=}$ \\
\hline 皇 & $\underset{m}{m}$ & $\stackrel{D}{m}$ & $\sqrt{2}$ & $\underline{m}$ & $\stackrel{+}{ \pm}$ & $\stackrel{5}{\square}$ & $\stackrel{2}{=}$ & $\stackrel{n}{m}$ & $\stackrel{m}{m}$ & $\stackrel{\infty}{=}$ & $\stackrel{m}{m}$ & $\stackrel{\infty}{m}$ \\
\hline 胥 & - & $\frac{n}{7}$ & $\stackrel{0}{m}$ & r্ & $\ddot{\dot{\theta}}$ & $\frac{0}{m}$ & $\begin{array}{l}\text { Yे } \\
\text { ñ }\end{array}$ & $\underset{m}{0}$ & ñ & $\ddot{b}$ & $\vec{m}$ & ị̃ \\
\hline 吕 或 & 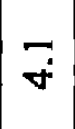 & $\ddot{m}$ & $\vec{m}$ & $\stackrel{0}{\dot{v}}$ & $\mid$ & $m$ & $\begin{array}{l}0 \\
m\end{array}$ & $\stackrel{\nabla}{m}$ & $m$ & $n$ & $n$ & m \\
\hline 垔 & ro & 2 & $\stackrel{\infty}{r}$ & $\pi$ & 車 & $\stackrel{0}{1}$ & 2 & $\stackrel{\infty}{r}$ & 9 & $\stackrel{\infty}{\Omega}$ & $\stackrel{\infty}{r}$ & 芯 \\
\hline 宫 & $\frac{m}{n}$ & $\frac{\pi}{n}$ & 용 & 茫 & $\vec{n}$ & $\vec{a}$ & $\frac{m}{n}$ & $\frac{0}{1}$ & $\pi$ & $\frac{0}{2}$ & $\stackrel{\circ}{\frac{1}{N}}$ & $\stackrel{-}{N}$ \\
\hline 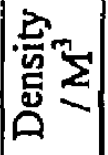 & $\infty$ & $\underline{0}$ & $\stackrel{N}{\Omega}$ & $\infty$ & 이 & 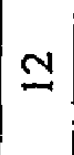 & $\infty$ & 으 & 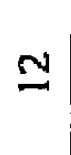 & $\infty$ & 으 & 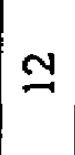 \\
\hline 동 & & 营 & & & ס & & & 点 & & & ס्ठّ & \\
\hline$\frac{N}{25} \infty$ & \multicolumn{6}{|c|}{$n$} & \multicolumn{6}{|c|}{ 으 } \\
\hline
\end{tabular}




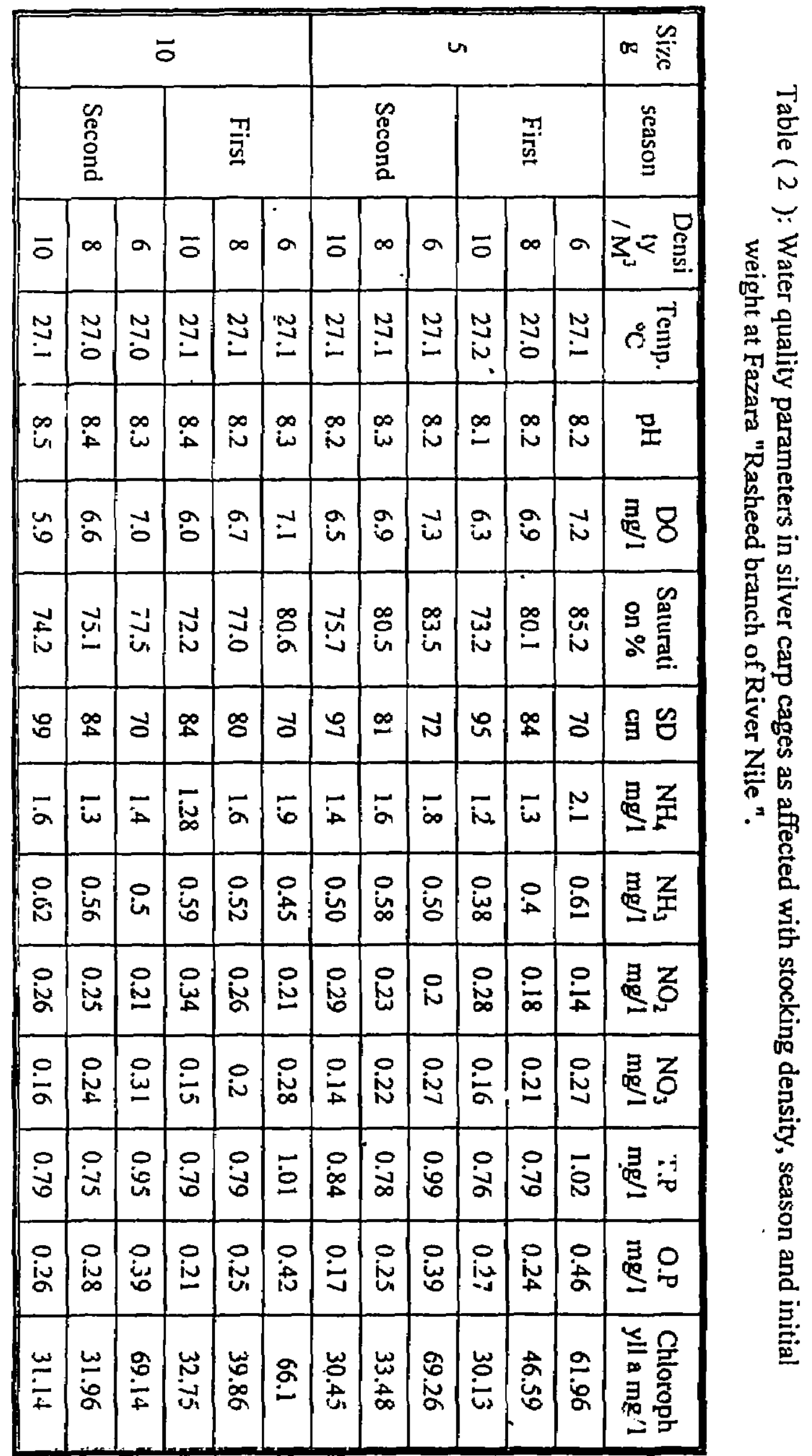




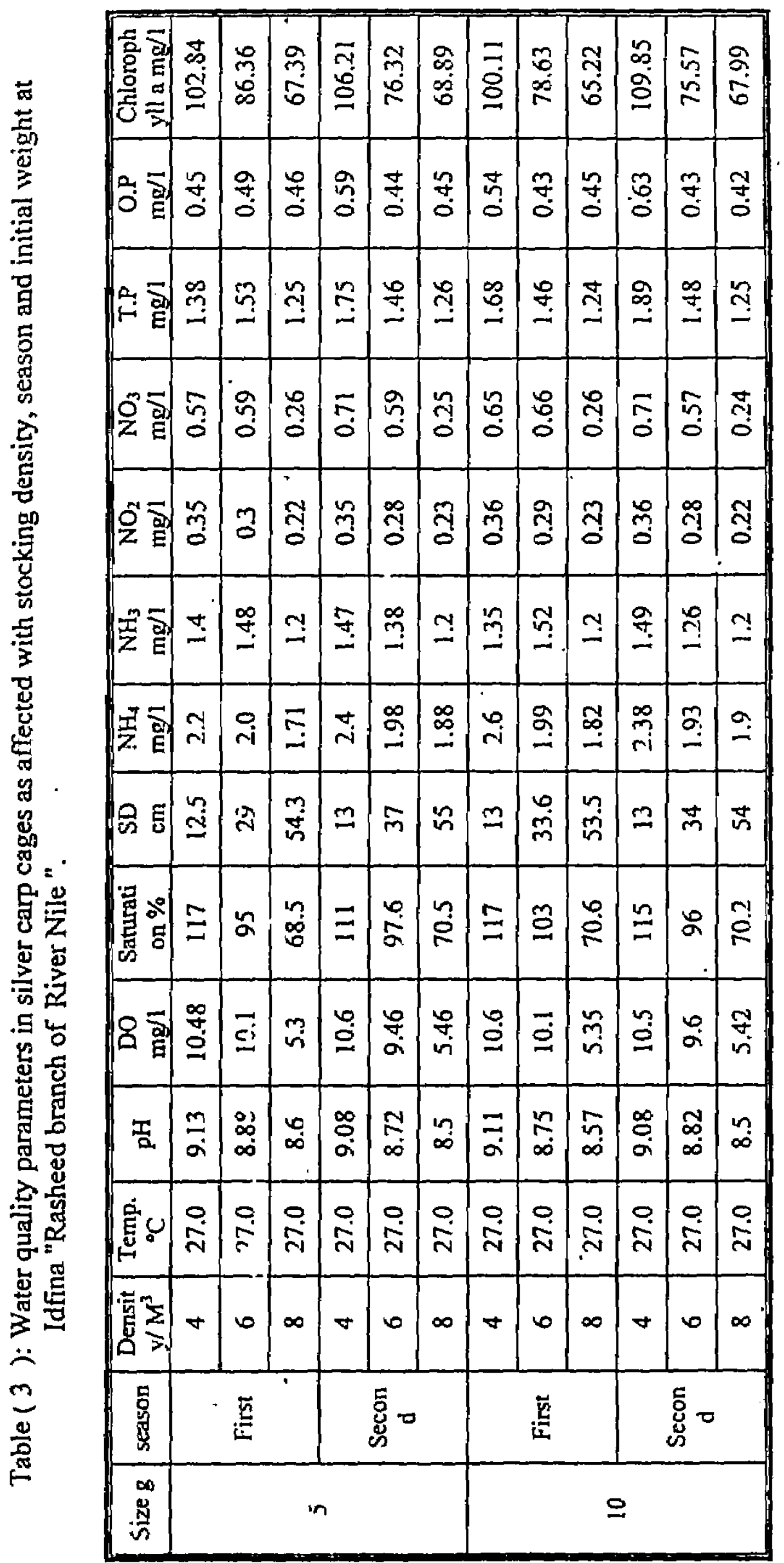




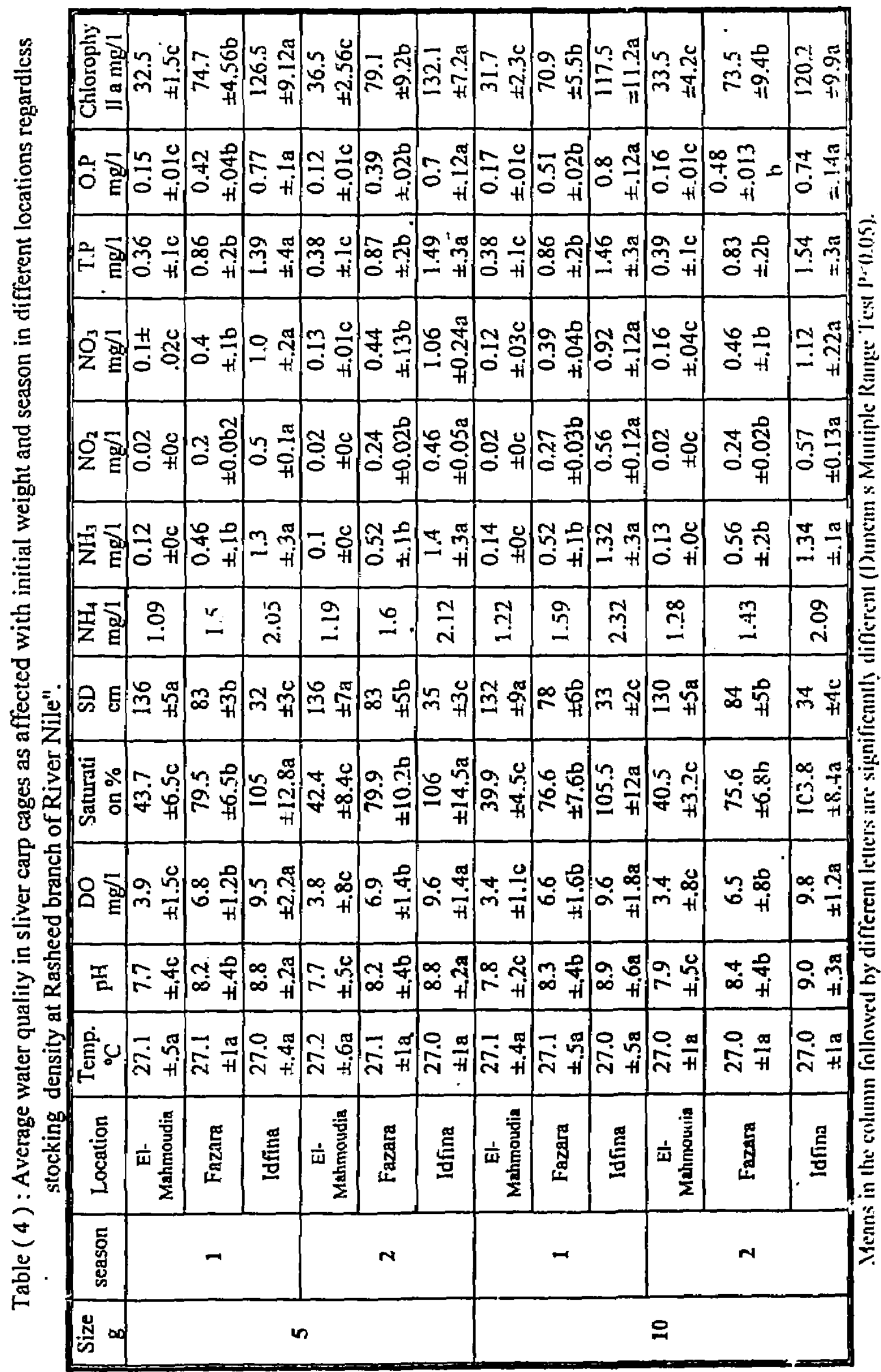




\begin{tabular}{|c|c|c|c|c|c|c|c|c|c|c|c|c|c|c|}
\hline \multicolumn{6}{|c|}{5} & \multicolumn{6}{|c|}{ יני } & \multirow{2}{*}{\multicolumn{2}{|c|}{ 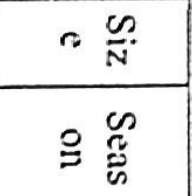 }} & $\overrightarrow{\tilde{\sigma}}$ \\
\hline \multicolumn{3}{|c|}{10} & \multicolumn{3}{|c|}{ - } & \multicolumn{3}{|c|}{$N$} & \multicolumn{3}{|c|}{-} & & & \\
\hline$\pi$ & $\overline{0}$ & $\infty$ & $\bar{N}$ & $\overline{0}$ & $\infty$ & $\bar{N}$ & $\overline{0}$ & $\infty$ & $\bar{N}$ & $\overline{0}$ & $\infty$ & 宓 & 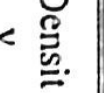 & 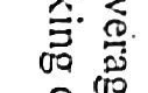 \\
\hline$\stackrel{\vec{N}}{N}$ & ठै & $\begin{array}{l}\text { O } \\
\text { is }\end{array}$ & $\underset{ \pm}{\tilde{s}}$ & $\begin{array}{l}\infty \\
\tilde{0}\end{array}$ & 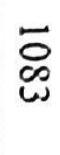 & 吕 & రి & 离 & 空 & N & ర్ & 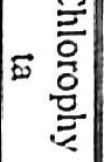 & 4 & 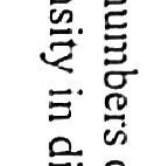 \\
\hline 古 & $\frac{\omega}{a}$ & 官 & $\check{E}$ & $\stackrel{N}{D}$ & E. & 䓃 & $\ddot{z}$ & $\stackrel{u}{\infty}$ & $\underset{N}{\omega}$ & 忍 & $i_{i n}^{u}$ & ש. & 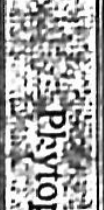 & 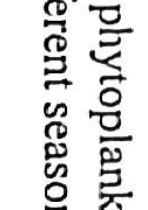 \\
\hline 응 & 홍 & $\tilde{w}$ & $\overline{8}$ & 홍 & 응 & $\bar{\omega}$ & कू & $\bar{u}_{0}$ & कू & $\stackrel{N}{N}$ & $\stackrel{10}{ \pm}$ & 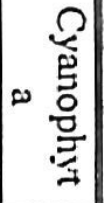 & 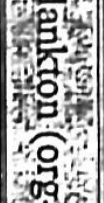 & 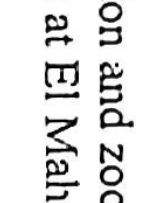 \\
\hline $\overrightarrow{0}$ & N & $\underline{\simeq}$ & ठै & $\ddot{0}$ & vo & ă & $\stackrel{b}{+}$ & 古 & $\stackrel{M}{\oplus}$ & $\stackrel{b}{D}$ & w & 品 & 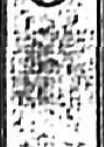 & 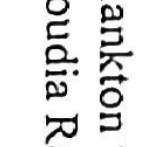 \\
\hline 怘 & N & $\vec{E}$ & g & $\underset{\sim}{\tilde{N}}$ & $\overrightarrow{\tilde{\omega}}$ & ğ & $\begin{array}{l}\vec{\infty} \\
\stackrel{\$}{ \pm}\end{array}$ & $\frac{N}{\mathrm{O}}$ & $\bar{\varpi}$ & a & $\begin{array}{l}\overrightarrow{0} \\
\text { iे } \\
\text { in }\end{array}$ & \begin{tabular}{ll}
0 & -1 \\
\hdashline & 0 \\
0 & 0 \\
0 & 0
\end{tabular} & 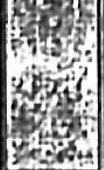 & 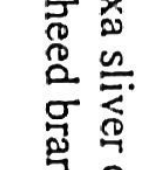 \\
\hline 菅 & 点 & $\vec{\infty}$ & 후 & 옹 & $\tilde{\omega}$ & $\vec{y}$ & $\bar{N}$ & $\stackrel{\infty}{\infty}$ & $\bar{a}$ & 웅 & $\bar{\omega}$ & 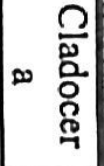 & 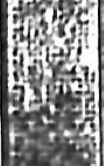 & 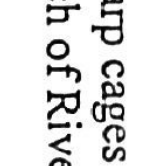 \\
\hline 心 & ฉั & 음 & $\varpi$ & $\stackrel{\infty}{=}$ & $\overrightarrow{0}$ & $\overrightarrow{0}$ & $\stackrel{\circ}{\circ}$ & 虫 & $\vec{\infty}$ & & 웅 & 冚 & $\begin{array}{l}20 \\
80 \\
80\end{array}$ & 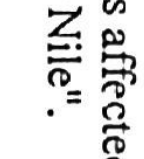 \\
\hline$\stackrel{\circ}{\circ}$ & ஓి & gి & చే & ŭ & ㅇ & 具 & 8 & in & $\vec{u}$ & జ్ & ò & कि & 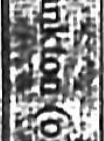 & 5 \\
\hline$\vec{\omega}$ & $\vec{A}$ & $\infty$ & $\vec{A}$ & $\stackrel{N}{N}$ & $\doteq$ & 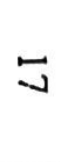 & $\vec{\infty}$ & $\infty$ & $\vec{n}$ & $\overrightarrow{0}$ & $\omega$ & 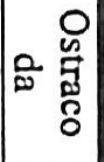 & 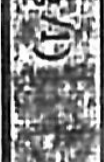 & 兽. \\
\hline$\hat{\overrightarrow{0}}$ & $\underset{\omega}{\omega}$ & $\underset{\sim}{\sigma}$ & $\underset{\infty}{\infty}$ & 응 & $\underset{\sigma}{\omega}$ & $\ddot{\sim}$ & NO & w & $\underset{\perp}{\omega}$ & $\tilde{\Omega}$ & $\underset{+}{\omega}$ & 잉 & 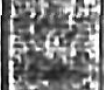 & \\
\hline
\end{tabular}




\begin{tabular}{|c|c|c|c|c|c|c|c|c|c|c|}
\hline (1) & ¿̊. & 悹 & 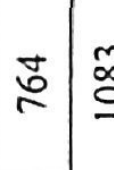 & $\infty_{2}^{\infty}$ & 总 & & 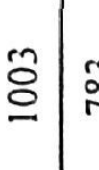 & & gे & în \\
\hline 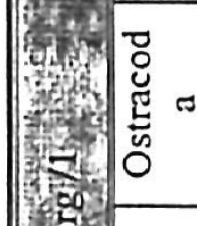 & $\begin{array}{l}\infty \\
\infty\end{array}$ & in & $\vec{N} \ddot{G}$ & i & 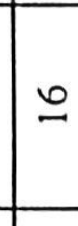 & \pm & m & $: 5$ & & $\because$ \\
\hline ״ & & $\underline{\vec{\Phi}}$ & $\Xi:=$ & 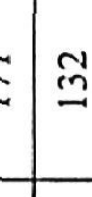 & $\stackrel{\circ}{\circ}$ & $\underline{\tilde{S}}$ & $\underline{\Xi}$ & 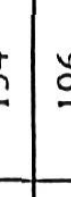 & $\underline{\text { n }}$ & 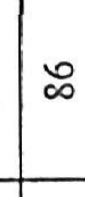 \\
\hline 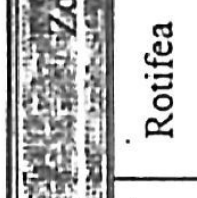 & 号 & $\begin{array}{l}5 \\
q\end{array}$ & 苛 & $\frac{m}{7}$ & $\overbrace{\text { సे }}^{n}$ & $\mid \begin{array}{l}\infty \\
\xi \\
q\end{array}$ & $\frac{2}{7}$ & $\vdots$ & $\vec{m}$ & 㑒 \\
\hline rit & & 系 & $\stackrel{\sim}{\approx} \leftrightarrows$ & ${ }^{\infty}$ & స్ & 亲 & âm: & $\xi^{\circ}$ & 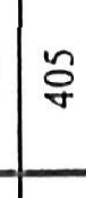 & $\stackrel{2}{*}$ \\
\hline (2) & & $\mid$ & 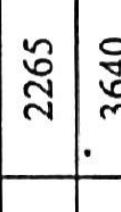 & 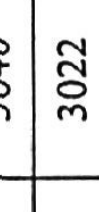 & 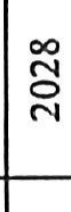 & $\underset{m}{m}$ & 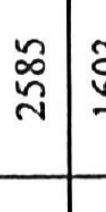 & $a_{3}^{\prime}$ & & 粱 \\
\hline 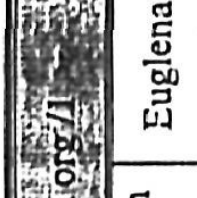 & 5 & q & $\tilde{m}$ & $\begin{array}{l}\hat{f} \\
\hat{f}\end{array}$ & 总 & 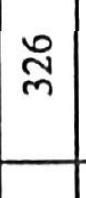 & 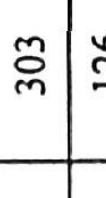 & $=$ & : & 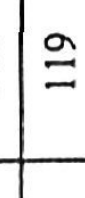 \\
\hline 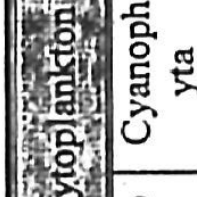 & d & $\mid$ & $\vec{q}$ & 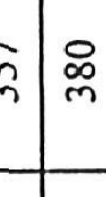 & สำ & 免 & $\vec{\Phi} \mid ?$ & 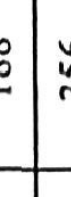 & : & : \\
\hline 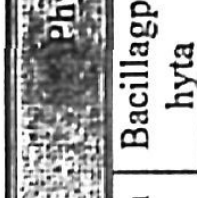 & $\stackrel{\Xi}{\Xi}$ & $\mid z \alpha$ & 离 & 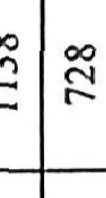 & $\mid \stackrel{\circ}{q}$ & 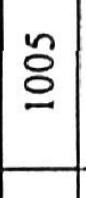 & : & $\begin{array}{l}b \\
t \\
t\end{array}$ & 吾 & F \\
\hline & 足 & $\mid$\begin{tabular}{|c}
0 \\
0 \\
0 \\
0
\end{tabular} & $\stackrel{\tilde{n}}{=} \cdot \stackrel{\tilde{0}}{-}$ & 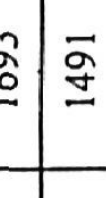 & $\stackrel{\circ}{\circ}$ & $\begin{array}{l}\text { 志 } \\
\vdots\end{array}$ & $\stackrel{\stackrel{\sim}{=}}{=}$ & $y$ & $\stackrel{\infty}{g}$ & 资 \\
\hline 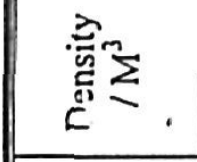 & 0 & $\infty$ & $=0$ &. & . & 0 & $\infty$ & & & 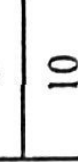 \\
\hline 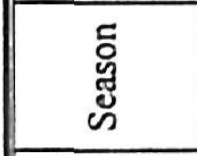 & & - & & $\mathrm{N}$ & & & - & & $\mathrm{N}$ & \\
\hline$\frac{\mathscr{V}}{i s}$ & & & n & & & & & & & \\
\hline
\end{tabular}




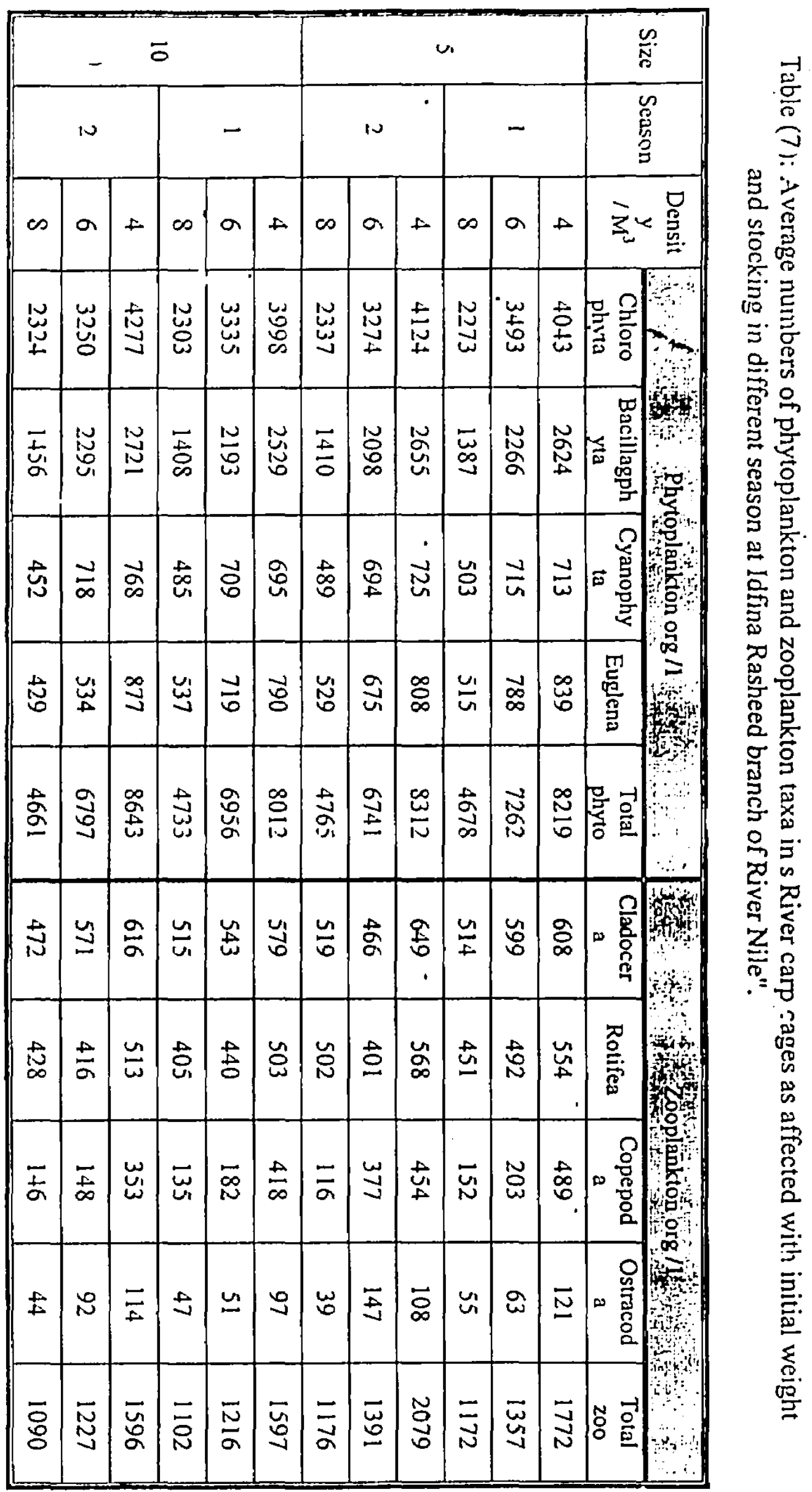




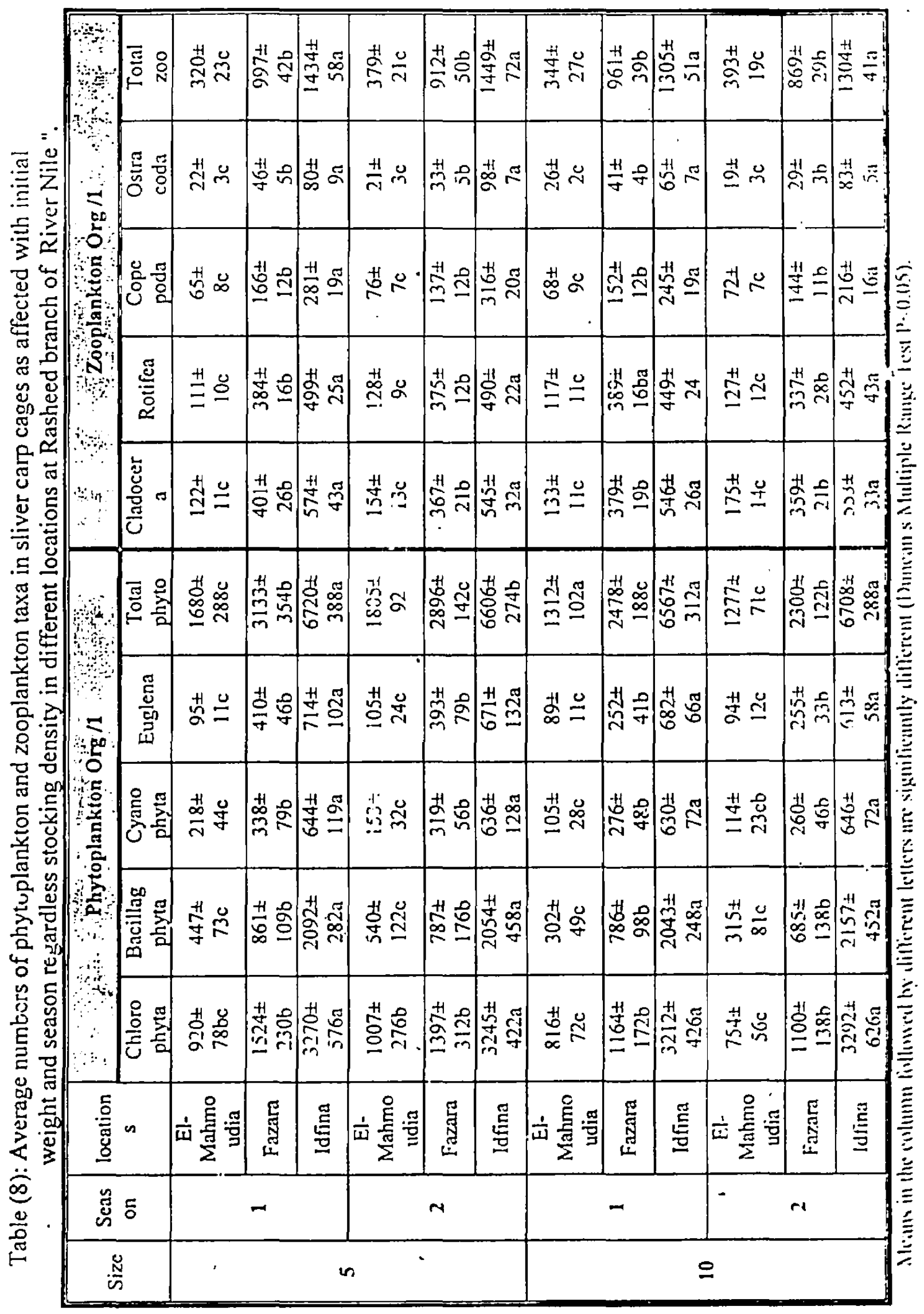




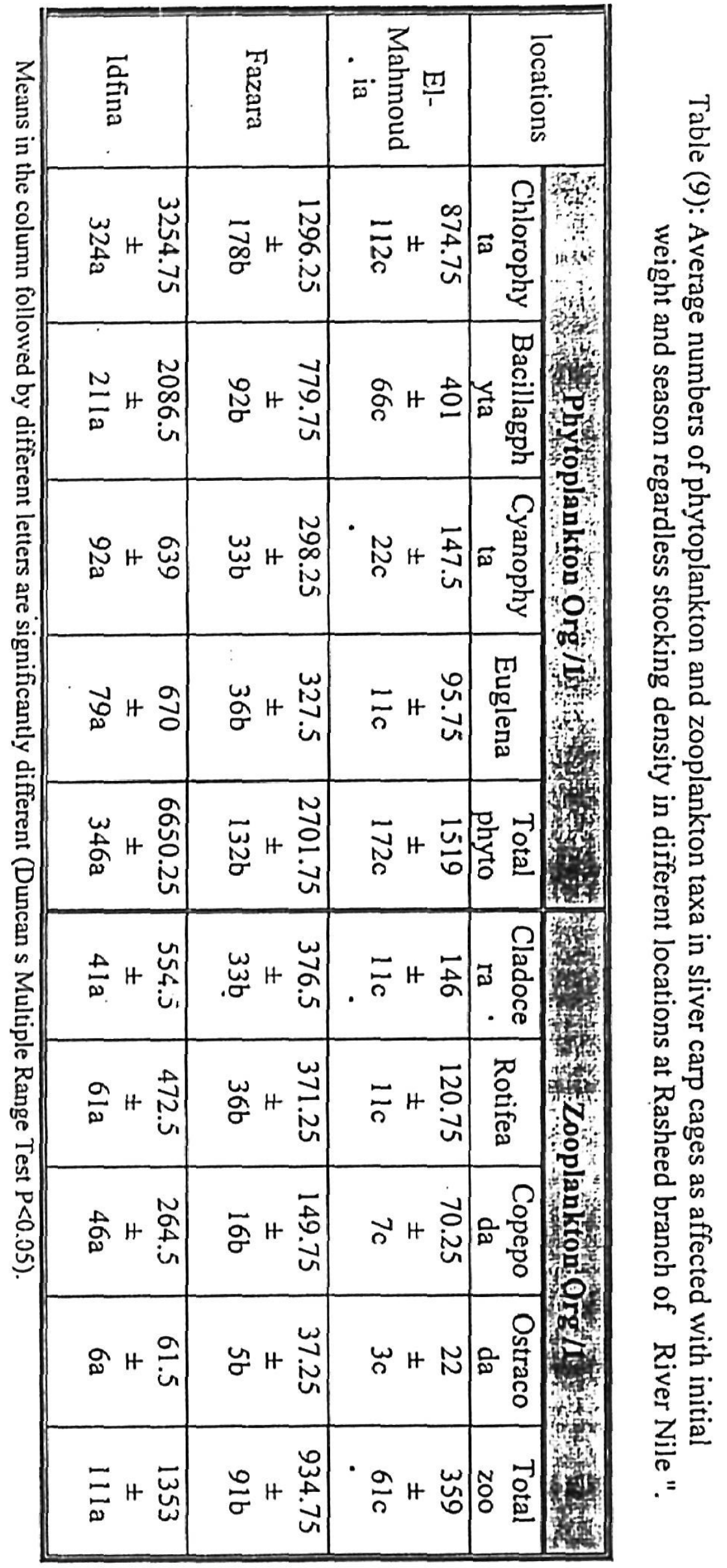




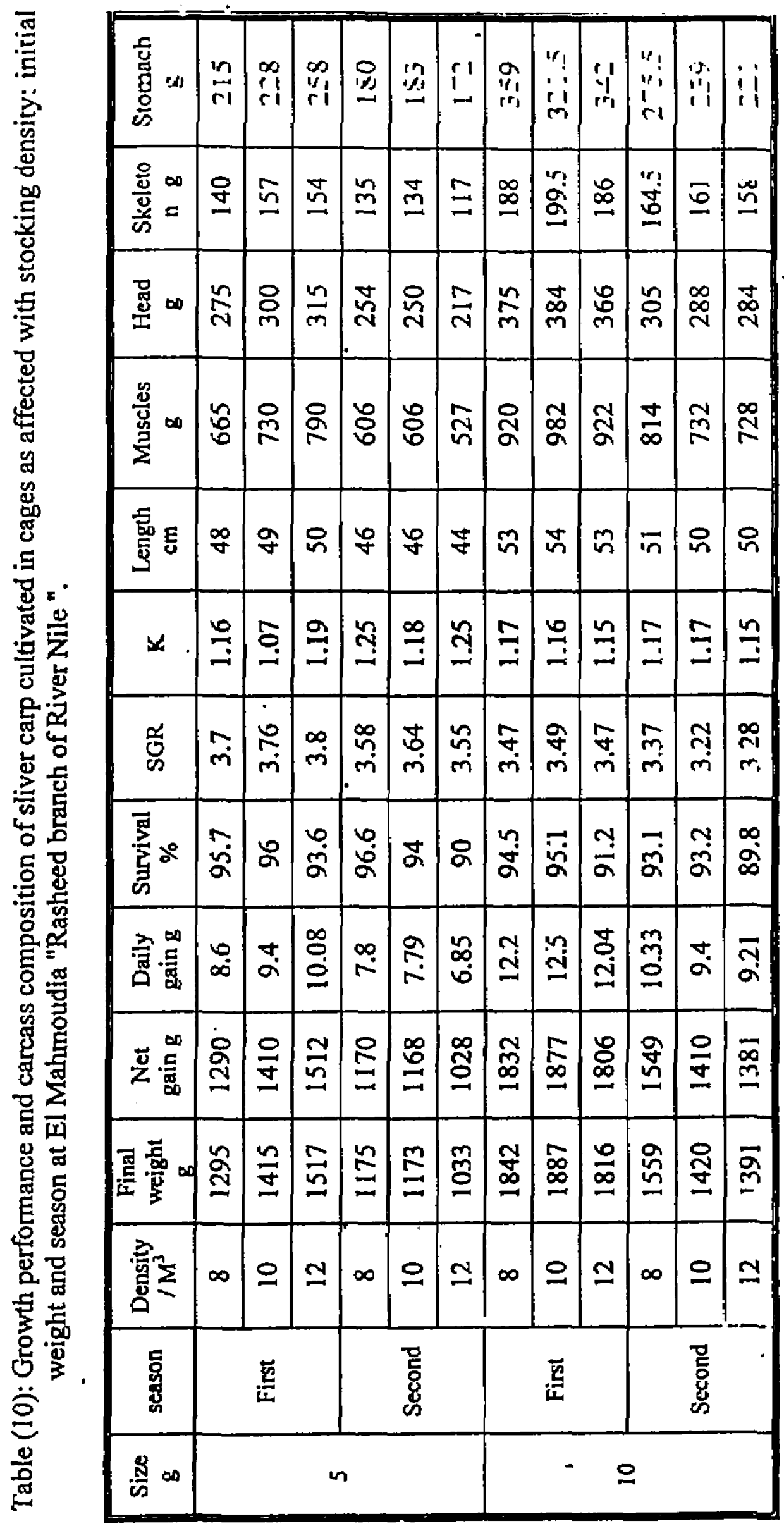




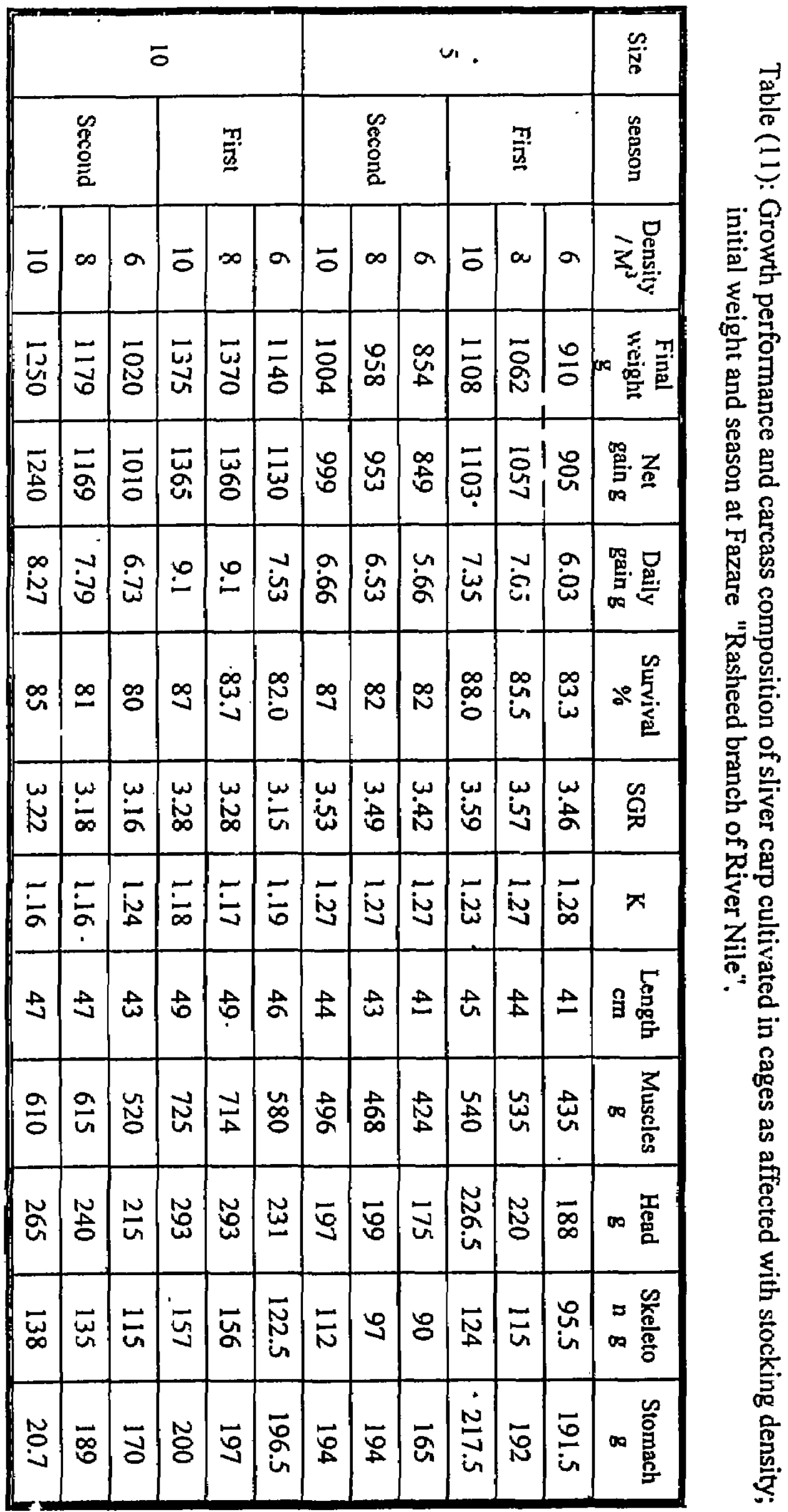




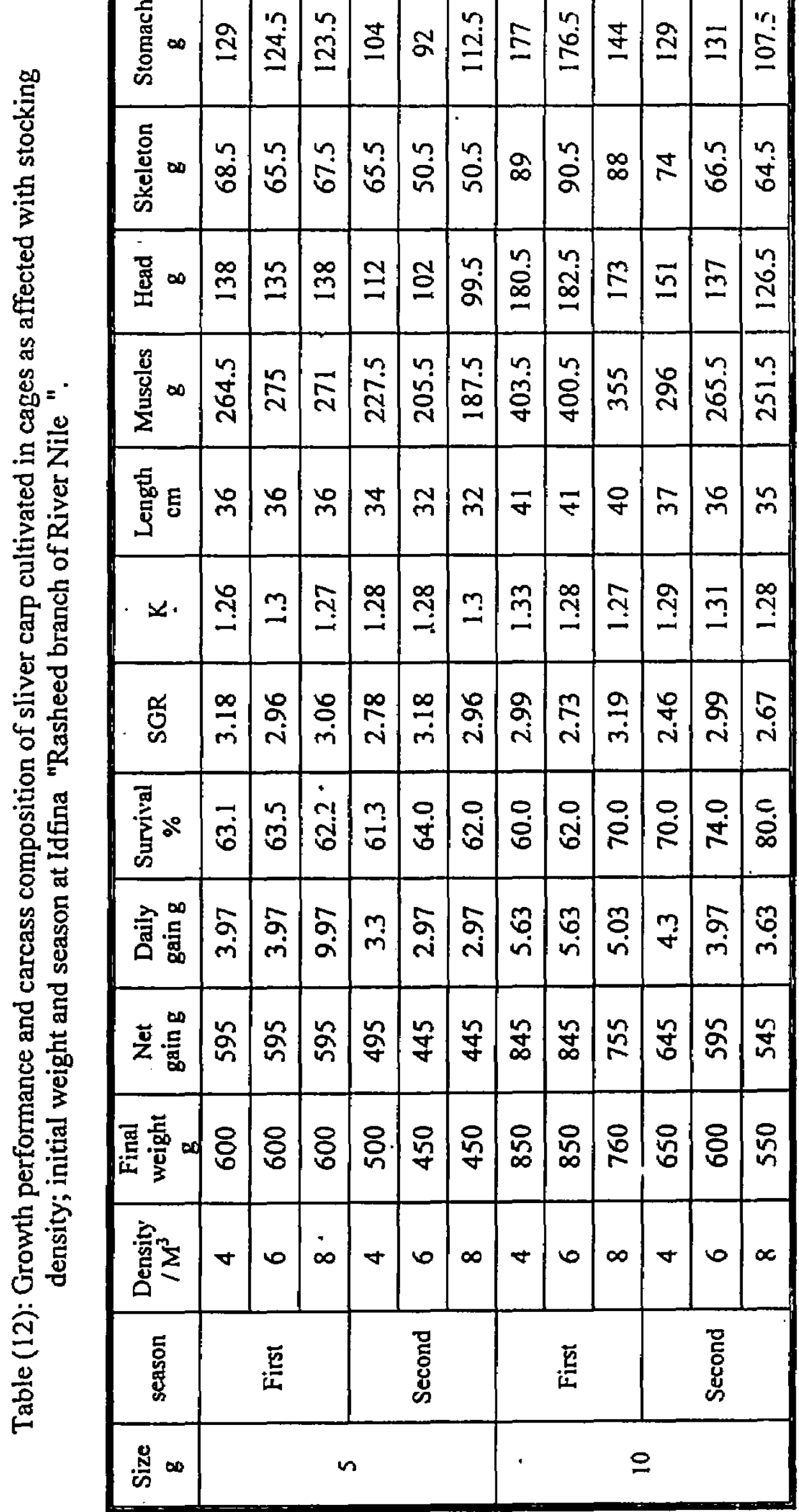




\begin{tabular}{|c|c|c|c|c|c|c|c|c|c|c|c|c|c|}
\hline \multicolumn{6}{|c|}{$\ddot{0}$} & \multicolumn{6}{|c|}{ un } & \multirow{2}{*}{$\frac{\infty \frac{\omega}{N}}{\approx}$} & \\
\hline \multicolumn{3}{|c|}{ 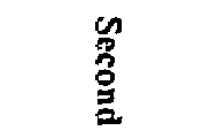 } & \multicolumn{3}{|c|}{ T] } & \multicolumn{3}{|c|}{$\begin{array}{l}n \\
0 \\
0 \\
0 \\
0\end{array}$} & \multicolumn{3}{|c|}{ 곡 } & & 2 \\
\hline$\stackrel{\overrightarrow{5}}{\vec{G}}$ & 苞 & 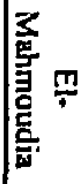 & $\overrightarrow{\bar{z}}$ & 喁 & 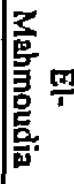 & 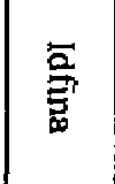 & 跑 & 氺 & 佘 & 苞 & 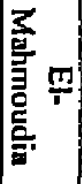 & 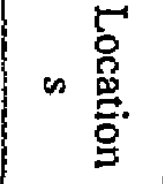 & 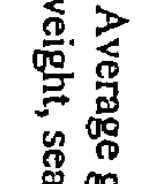 \\
\hline 용 & $\bar{\sigma}$ & $\bar{v}$ & $\stackrel{\infty}{0}$ & 式 & $\underset{\infty}{\infty}$ & $\vec{g}$ & 㟔 & 正 & 8 & $\bar{N}$ & 点 & 果高. & 总焉 \\
\hline ํํㅇ & $\overline{0}$ & E & $\stackrel{\infty}{0}$ & $\begin{array}{l}N \\
\infty \\
心\end{array}$ & $\mathfrak{\infty}_{\infty}^{\infty}$ & $\overrightarrow{\mathrm{N}}$ & 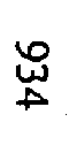 & $\bar{N}$ & un & . 忍 & $\vec{w}$ & 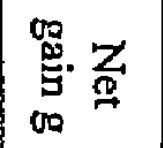 & 茝目 \\
\hline U) & io & $\begin{array}{l}0 \\
a\end{array}$ & r & $i^{\infty}$ & w & $\omega$ & in & $\frac{1}{\infty}$ & $\begin{array}{l}\omega \\
i g \\
-a\end{array}$ & $i_{n}^{\infty}$ & w & 兽 & 空含 \\
\hline$\stackrel{\vec{p}}{ \pm}$ & 啰 & is & 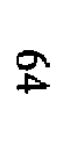 & 品 & 吕 & 怘 & $\underset{\omega}{\infty}$ & w & N & $\begin{array}{l}\infty \\
u \\
a\end{array}$ & 卓 & $\begin{array}{l}\text { w } \\
\text { d゚ }\end{array}$ & 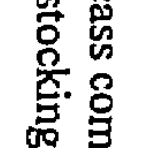 \\
\hline$\stackrel{N}{N}$ & w & $\begin{array}{c}w \\
i v \\
b\end{array}$ & oㅡㅁ & $\underset{N}{w}$ & $\prod_{\infty}^{\omega}$ & No & $\stackrel{\omega}{\infty}$ & W & $\begin{array}{l}\omega \\
\dot{y}\end{array}$ & w & $\sum_{v}^{w}$ & $\stackrel{0}{\Omega}$ & 莺总. \\
\hline iั & $\%$ & $\bar{a}$ & in & 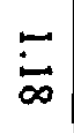 & 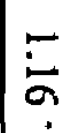 & in & $\bar{v}$ & 出 & $\bar{\infty}$ & 㤀 & $\dot{D}$ & 不 & $\Phi$ \\
\hline$\underset{\alpha}{\alpha}$ & $\vec{n}$ & $\underset{\omega}{u}$ & 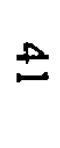 & $\frac{t}{a}$ & w & س & $\begin{array}{l}\mathrm{N} \\
\text { a }\end{array}$ & u & $\tilde{\alpha}$ & $\vec{\omega}$ & : & $\stackrel{9}{g}$ & 包总 \\
\hline$\underset{\Xi}{J}$ & 占 & $\vec{\infty}_{\infty}$ & $\underset{\infty}{\infty}$ & $\frac{a}{a}$ & $\stackrel{8}{ \pm}$ & $\stackrel{\sim}{\circ}$ & 总 & $\stackrel{M}{\infty}$ & $\stackrel{N}{O}$ & 岁 & +3 & 㸃 & $\begin{array}{l}0 . \\
5 \\
8 \\
0\end{array}$ \\
\hline $\bar{\infty}$ & 等 & 总 & $\bar{\sigma}$ & $\frac{N}{N}$ & $\underset{v}{w}$ & u & $\%$ & $\stackrel{N}{0}$ & $\tilde{w}$ & u & 莒 & 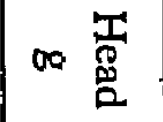 & $\begin{array}{l}\vec{D} \\
\mathbb{8} \\
\mathbb{8}\end{array}$ \\
\hline$\infty$ & 60 & $a$ & 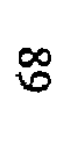 & $\vec{E}$ & $\ddot{0}$ & $u_{n}^{n}$ & 8 & $\overrightarrow{0}$ & $g$ & 丳 & $\overrightarrow{0}$ & $\stackrel{0}{\stackrel{0}{X}}$ & 劳 \\
\hline $\mathfrak{N}_{\substack{u \\
u}}$ & $\begin{array}{l}\infty \\
\infty \\
0 \\
0\end{array}$ & 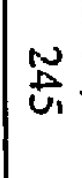 & $\vec{\alpha}$ & $\underset{\infty}{\sigma}$ & $\stackrel{\omega}{\rightleftarrows}$ & $\stackrel{\leftrightarrow}{\mathbf{\omega}}$ & $\underset{\not \infty}{\infty}$ & చ & s & 8 & $\underset{\perp}{\omega}$ & 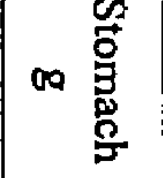 & 总泀: \\
\hline
\end{tabular}




\begin{tabular}{|c|c|c|c|c|c|c|}
\hline 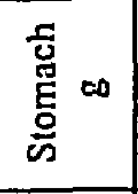 & 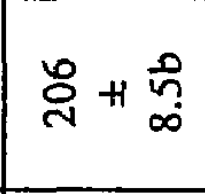 & $\widetilde{\Omega}+\stackrel{0}{0}$ & $\stackrel{n}{\Xi}+\frac{0}{\dot{\sigma}}$ & 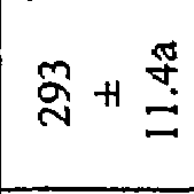 & 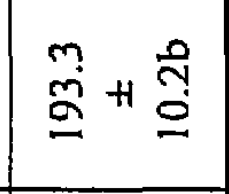 & 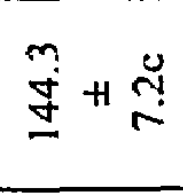 \\
\hline 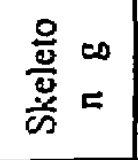 & 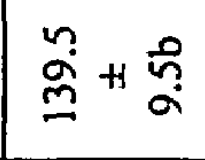 & 窇 + & 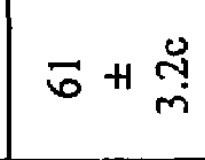 & $\stackrel{0}{=}+\stackrel{\overparen{n}}{=}$ & $\underline{m}+\stackrel{0}{q}$ & $\stackrel{n}{\infty}+\underset{\infty}{\infty}$ \\
\hline 蛋 & 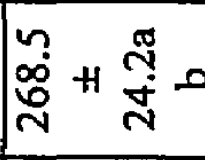 & $\stackrel{\infty}{\stackrel{i}{i}+\frac{0}{m}}$ & : & $m_{m}^{n}+\stackrel{\substack{n \\
m}}{\sim}$ & مั & 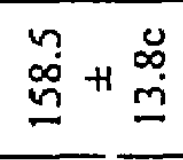 \\
\hline 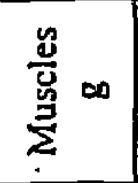 & 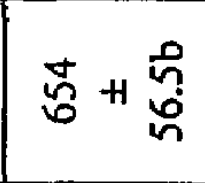 & $\underset{\forall}{\mathscr{b}}++\underset{\sim}{\sim}$ & . & 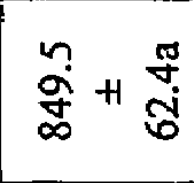 & 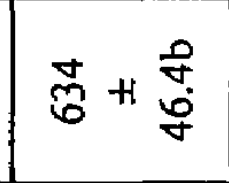 & 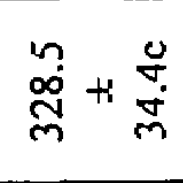 \\
\hline 駕 & $\frac{T}{q}+\frac{\pi}{4}$ & $\mathfrak{q}+\stackrel{\sim}{\sim}$ & 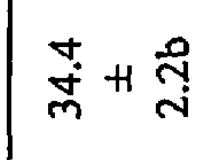 & $\stackrel{\infty}{\dot{n}}+\frac{d}{m}$ & $\stackrel{\leftrightarrow}{\dot{\sigma}}+\stackrel{\mathscr{d}}{\stackrel{\sim}{j}}$ & $\underset{m}{\infty}+\frac{0}{i}$ \\
\hline$x$ & $\stackrel{9}{=}+1 \frac{0}{0}$ & $\stackrel{\infty}{\dddot{N}}+\stackrel{\oplus}{=}$ & సิ + $\frac{\pi}{0}$ & $\stackrel{0}{=}+\frac{\pi}{0}$ & $\stackrel{-}{\rightrightarrows}+\frac{\mathscr{m}}{0}$ & $\stackrel{\text { जิ }}{+}+\frac{\text { d }}{0}$ \\
\hline 柋 & 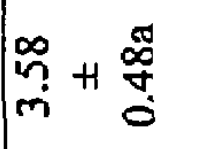 & $\frac{\vec{n}}{m}+\frac{\pi}{8}$ & 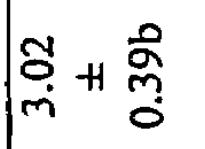 & $\prod_{m}^{\infty}+\stackrel{\frac{\pi}{g}}{0}$ & 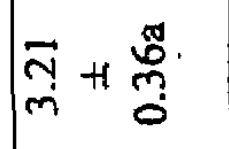 & 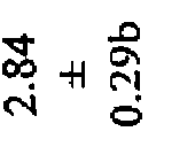 \\
\hline$: \sum_{0}$ & $\stackrel{2}{=}+$ 음 & $\overrightarrow{2}+\stackrel{2}{\sigma}$ & 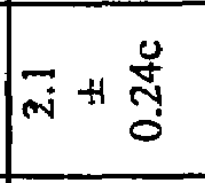 & $\stackrel{m}{\stackrel{m}{2}}+\stackrel{⿱ 乛 ⿻}{m}$ & $\bar{\infty}+1 \stackrel{\text { ș }}{.}$ & $\stackrel{\check{N}}{n}+\stackrel{\breve{m}}{\sigma}$ \\
\hline 密。 & $\stackrel{m}{\sigma}+\stackrel{\varpi}{g}$ & $\overrightarrow{\dot{\Phi}}+\underset{\sim}{\infty}$ & స్ㅇํ + & 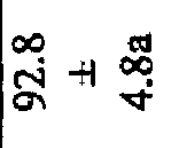 & 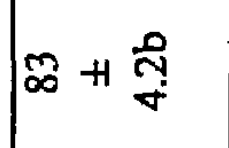 & $\ddot{\sigma}+\frac{u}{m}$ \\
\hline & $\vec{\nabla}++\underset{n}{\sim}$ & $\stackrel{\infty}{\stackrel{\infty}{*}+} \equiv$ & $\dddot{m}+\frac{8}{0}$ & 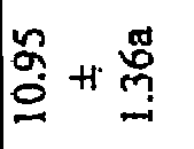 & $\sum_{\infty}^{\infty}++$ + & $\underset{+}{5}+\frac{\dot{+}}{0}$ \\
\hline$\underset{\mathrm{z}}{\mathrm{z}}$ & 䜦 & 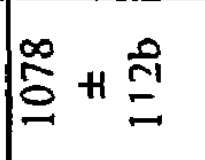 & 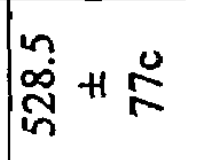 & 帒 & 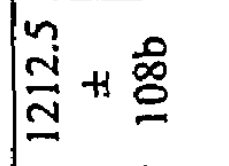 & 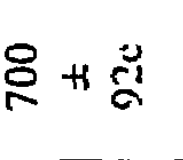 \\
\hline 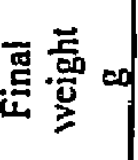 & 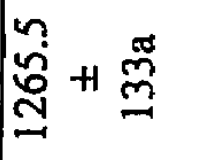 & $\stackrel{\infty}{\stackrel{0}{c}+} \stackrel{n}{\Xi}$ & 角 & 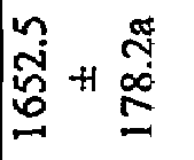 & : & $\frac{2}{2}+\frac{4}{0}$ \\
\hline 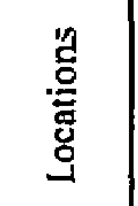 & 㐫言 & 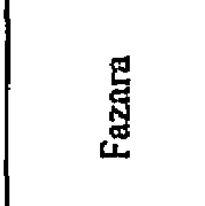 & 䞤 & 㐫总 & 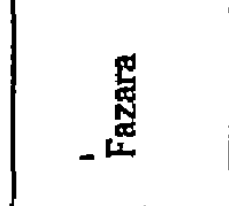 & 总 \\
\hline 站。 & & \multicolumn{3}{|c|}{$=$} \\
\hline
\end{tabular}



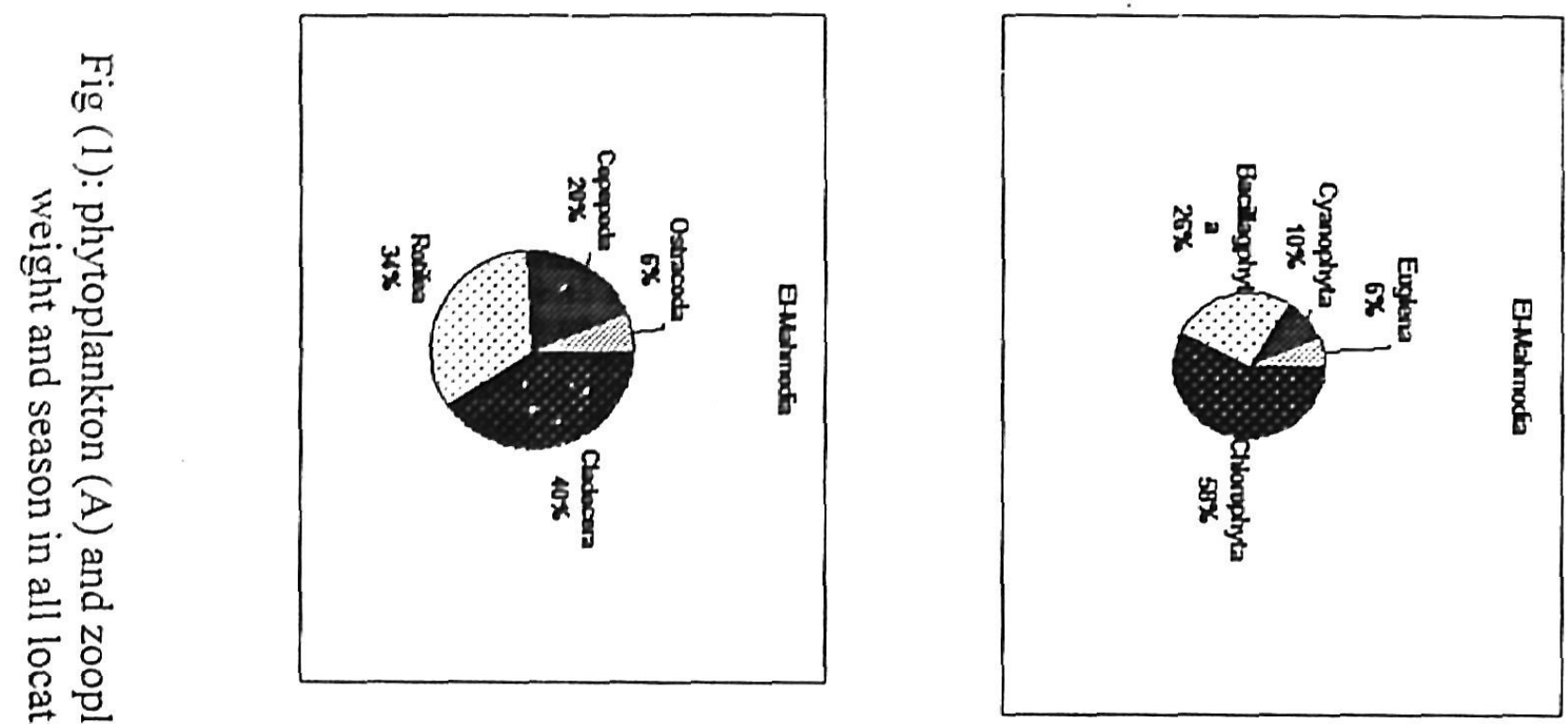

突突

号
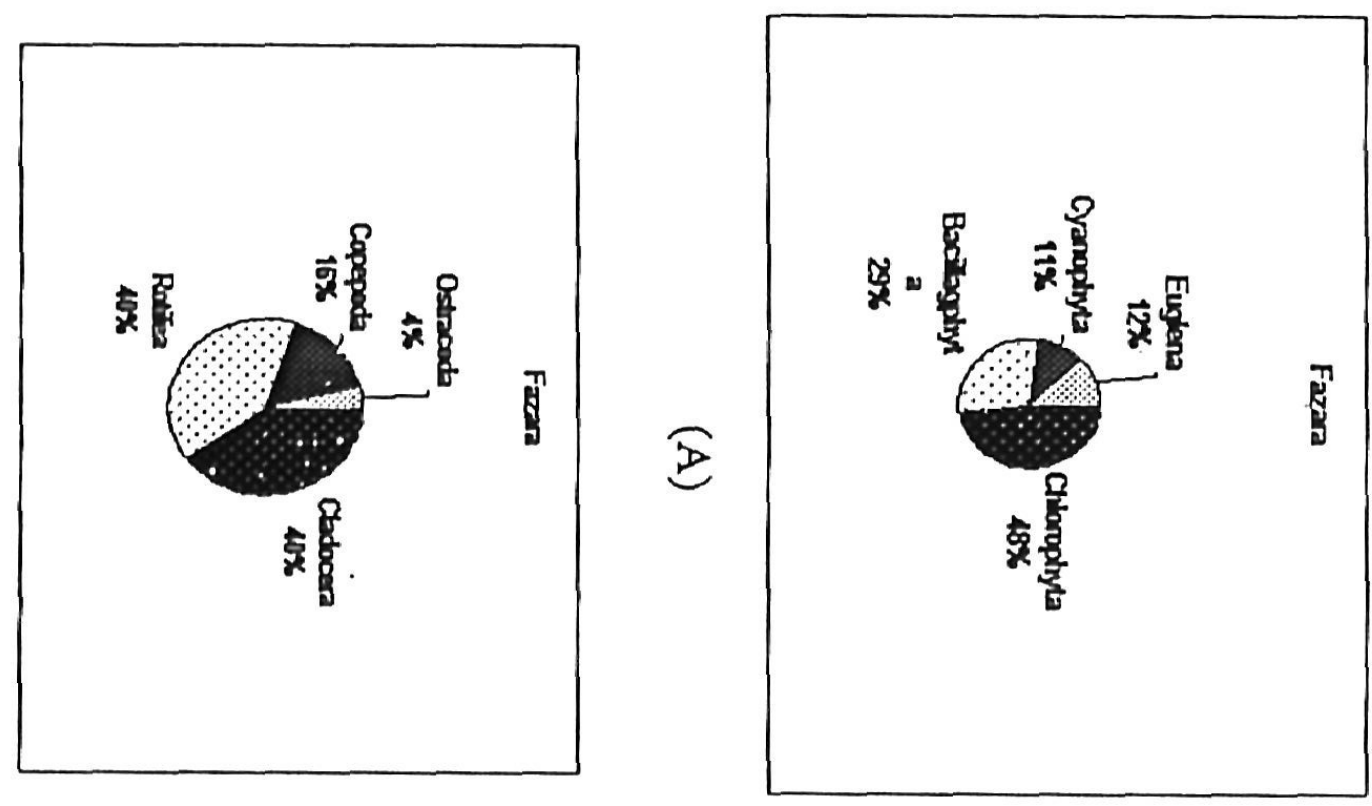

乘

寻

虫空.

चु छ

․ㅜㅇ.

要

(10

赵

古

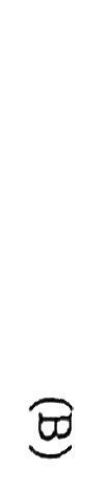

